\title{
Addition of homoeopathy in the diet of Japanese quails increases egg weight
}

\section{A adição da homeopatia na dieta de codornas japonesas aumenta o peso dos ovos}

\author{
Bruna de Souza Eberhart"; Jean Kaique Valentim²*; Rodrigo Garófallo Garcia ${ }^{3}$; \\ Felipe Cardoso Serpa ${ }^{1}$; Gisele Aparecida Felix; ; Mônica Filomena de Assis Souza5; \\ Bruna Barreto Przybulinski2; Vivian Aparecida Rios de Castilho2; Maria Fernanda de \\ Castro Burbarelli3; Cláudia Marie Komiyama ${ }^{3}$
}

\section{Highlights}

The homeopathic products increase the weight of quail eggs and of their components.

The diet containing $\mathrm{Ovosigo}^{\circledR}$ may lead to a greater availability of calcium.

Homeopathy it is considered an alternative to allopathic medicines in quail breeding.

\begin{abstract}
This study aims to evaluate the effects of the inclusion of different homoeopathic products on the diet of laying quails. We used 200 Japanese quails (Coturnix coturnix japonica) distributed in a completely randomized design consisting of the adoption of four experimental diets, with eight replicates of five quails each. The treatments were control (without additives), calcium carbonate (vehicle used in the products), Fertsigo ${ }^{\circledR}$, and Ovosigo $^{\oplus}$. We determined the performance, egg quality, and blood biochemical profile of quails. The data were submitted to Tukey test at $5 \%$ probability. There was a significant effect of the homeopathic products Fertsigo ${ }^{\circledR}$ and Ovosigo ${ }^{\circledR}$ on the variables egg weight, yolk, albumen, and shell percentage. It did not affect the performance and blood biochemical profile $(p>0.05)$. The addition of the homoeopathic product Ovosigo ${ }^{\circledR}$ and FertSigo ${ }^{\circledR}$ in diets of Japanese quails at the laying phase is recommended because they resulted in the better weight of the egg and its components. Thus, the application of homoeopathy in the production of

1 Students of the Master's Course in Animal Science of Department of Animal Science, Universidade Federal da Grande Dourados, UFGD, MS, Dourados, Brazil. E-mail: brunasouzae@hotmail.com; felipe.c.serpa@gmail.com

2 Students of the Doctoral Course of the Graduate Program in Animal Science of Department of Animal Science, Universidade Federal da Grande Dourados, UFGD, MS, Dourados, Brazil. E-mail: kaique.tim@hotmail.com; bruna-b@ hotmail.com; viviancastilho@live.com

3 Profs. Drs., from the Graduate Program in Animal Science of Department of Animal Science, Universidade Federal da Grande Dourados, UFGD, MS, Dourados, Brazil. E-mail: rodrigogarcia@ufgd.edu.br; fariakita@gmail.com; claudiakomiyama@gmail.com

${ }^{4}$ Profa Dra, Veterinary Medicine Course, Department of Veterinary Medicine, Centro Universitário da Grande Dourados, UNIGRAN, MS, Brazil. E-mail: giselefelix@gmail.com

5 Researcher, SIGO, Homeopathy, Campo Grande, MS, Brazil. E-mail: monica.a.souza@gmail.com

* Author for correspondence
\end{abstract}

Received: Sept. 21, 2020 - Approved: Feb. 24, 2021 
quails is a viable practice, since it is easy to manage, has a reduced cost, and exerts positive effects on the performance of quails.

Key words: Quail breeding. Egg production. Homeopathy. Ultra-diluted medicine.

\section{Resumo}

Este estudo teve por objetivo avaliar a ação da inclusão de diferentes produtos homeopáticos na dieta de codornas poedeiras. Foram utilizadas 200 codornas japonesas (Coturnix Coturnix Japonica), distribuídas em delineamento inteiramente casualizado, consistindo na adoção de quatro dietas experimentais com oito repetições de cinco codornas cada. Os tratamentos foram: Controle (sem aditivos); Carbonato de cálcio (veículo utilizado nos produtos); Fertsigo ${ }^{\circledR}$ e Ovosigo ${ }^{\circledR}$. O desempenho, a qualidade dos ovos e o perfil bioquímico do sangue das codornas foram avaliados e os dados submetidos ao teste de Tukey ao nível de $5 \%$ de probabilidade. Houve efeito significativo do produto homeopático Fertsigo ${ }^{\circledR}$ e Ovosigo ${ }^{\circledR}$ para as variáveis peso do ovo, gema e albúmen e porcentagem de casca. Não foram afetados o desempenho e o perfil bioquímico do sangue $(p>0,05)$. É indicada a adição dos produtos homeopáticos Ovosigo ${ }^{\circledR}$ e FertSigo $^{\circledR}$ em dietas para codornas japonesas na fase de postura, pois resultaram no melhor peso do ovo e seus componentes. Assim, a aplicação da homeopatia na produção de codornas pode ser uma prática viável, pois é de fácil administração, com custo reduzido e com efeitos positivos no desempenho das codornas.

Palavras-chave: Coturnicultura. Produção de ovos. Homeopatia. Medicamento ultra-diluído.

\section{Introduction}

The current market requires the supply of healthy products to the population considering ethics aspects in the breeding of animals. In this sense, the indiscriminate use of medicines as performance enhancers in animal production has generated a greater engagement on the part of researchers. Problems arise from the use of antibiotics in animals (Valentim et al., 2018), mainly regarding the increase in pathogen resistance.

The demand for sustainable animal production systems and the creation of precision animal nutrition lead the entire productive sector to search for new compounds. Such new compounds may replace antimicrobials as performance enhancers without causing risks to animals and leaving residues in products intended for human consumption (Lemos et al., 2017).
Obtaining a substitute, at the height of these agents, and a better understanding of the mechanisms of action of antimicrobials as performance enhancers is of relevance (A. V. Souza et al., 2020). Performance enhancers have been the focus of research of several scholars, and the proposals hitherto presented have been diverse, such as mannanoligosaccharides (Chacher et al., 2017). Other mathods include prebiotics (Biswas, Mohan, Raza, Mir, \& Mandal, 2019), probiotics (Ferdous et al., 2019), exogenous enzymes (Cowieson \& Kluenter, 2019), functional oils originated from plants that have nutraceutical properties (Gandra, Nunes Gil, Gandra, Takiya, \& Gobesso, 2017), and homoeopathy (Souza, 2002; Souza Oliveira et al., 2020).

Homoeopathy is a specific physiological stimulus therapy, in which the product is chosen according to particular 
needs (Teixeira \& Carneiro, 2017; Teixeira, 2018). Possible causes of a decreased animal development, as well as environmental aspects involving animal production, needs further research (Costa, Araújo, \& Freitas, 2009). The basic principle of homeopathy is the use of active substances prepared from plants, minerals, or diseased tissues (Costa, Queiroz, Souza, Zúccari, \& Costa, 2014). Homeopathy is recommended because it has a fast effect, leaves no residues in animal products, and increases animal productivity (Pires, 2005).

Therefore, the objective of this work is to evaluate the effects of different homoeopathic products on the animal performance, egg quality, and blood biochemical profile of Japanese quails (Coturnix coturnix japonica).

\section{Material and Methods}

The experiment was conducted at the quail breeding sector in the experimental facilities of the Faculty of Agrarian Sciences of the Federal University of Grande Dourados (FCA/UFGD), Dourados, MS, Brazil. All procedures and the management of animals were carried out with the approval of the Ethics Committee on the Use of Animals of the University Center of Grande Dourados (Unigran/Dourados), under protocol number 052/18. We used 200 Japanese quails (Coturnix coturnix japonica), weighted and classified them according to body weight (5\% \pm general mean). The quails were acquired from a commercial company at approximately 25 days of age. They were kept for 20 days in adaptation until they reached $80 \%$ of posture to start the experiment, which was divided into two experimental periods of 28 days. The homoeopathic products were purchased from a commercial company and administered orally at a dose of $0.02 \mathrm{~g} / q u a i l / d a y$, included in the feed provided for quails.

The quails were housed in metal cages in a conventional laying shed containing two air conditioners to control the temperature and humidity of the aviary. The quails were allocated in batteries arranged in parallel, on five floors with gutter-like feeders and nippletype drinking fountains. There were five floors $25 \mathrm{~cm}$ wide, $35 \mathrm{~cm}$ long, and $20 \mathrm{~cm}$ high, corresponding to an area of $175 \mathrm{~cm}^{2} /$ housed quail.

Water was supplied ad libitum, while feed was supplied twice a day in portions of 30 grams per quail/day. The quails were distributed in a completely randomized design, with four treatments and eight replications of five quails. The treatments were control (CT), CT + addition of $0.02 \mathrm{~g}$ of calcium carbonate/ quail/day (vehicle used in homeopathic products), CT + 0.02 g/quail/day of Fertsigo ${ }^{\circledR}$ (Sepia, succus $15 \mathrm{CH}$, Sulphur $10 \mathrm{CH}$, vehicle, inert q.s.p.), and CT + addition of 0.02 g/quail/ day of Ovosigo $^{\circledR}$ (Solanum lethale $12 \mathrm{CH}$, Silicea terra $12 \mathrm{CH}$, Natrum muriaticum $30 \mathrm{CH}$, Calcarea phosphorica $30 \mathrm{CH}$, Sulphur $12 \mathrm{CH}$, vehicle, inert q.s.p.).

The experimental diets based on ground corn and soybean meal (Table 1) were formulated according to the nutritional requirements for the species and the phase, considering the chemical composition of foods of the poultry and pig tables described by Rostagno et al. (2017). The 16-hour/daylight program was adopted. The maximum and minimum temperatures were daily measured using a thermal hygrometer and the relative humidity was at least $51.4 \pm 1.4$ (\%). 
Table 1

Levels of assurance of the enzymatic-bacterial inoculant used in the experiment

\begin{tabular}{|c|c|c|c|c|}
\hline Ingredients & Control & Carbonate & FertSigo $^{\circledR}$ & OvoSigo $^{\circledR}$ \\
\hline Corn Meal & 48.69 & 48.69 & 48.69 & 48.69 \\
\hline Soybean Meal & 34.07 & 34.063 & 34.07 & 34.07 \\
\hline Oil & 2.00 & 2.00 & 2.00 & 2.00 \\
\hline Calcium Carbonate & 5.24 & 5.24 & 5.24 & 5.24 \\
\hline Mineral Core & 4.00 & 4.00 & 4.00 & 4.00 \\
\hline Inert & 6.00 & 5.93 & 5.93 & 5.93 \\
\hline Homeopathy & 0.00 & 0.07 & 0.07 & 0.07 \\
\hline \multicolumn{5}{|c|}{ Calculated nutritional composition } \\
\hline Metabolizable energy (kcal/kg) & 2800.00 & 2800.00 & 2800.00 & 2800.00 \\
\hline Crude protein (\%) & 19.46 & 19.46 & 19.46 & 19.46 \\
\hline Digestible lysine (\%) & 1.080 & 1.080 & 1.080 & 1.080 \\
\hline Methionine+Cystine (\%) & 0.94 & 0.94 & 0.94 & 0.94 \\
\hline Tryptophan digs. (\%) & 0.23 & 0.23 & 0.23 & 0.23 \\
\hline Threonine digs. (\%) & 0.68 & 0.68 & 0.68 & 0.68 \\
\hline Calcium (\%) & 3.07 & 3.07 & 3.07 & 3.07 \\
\hline Match available (\%) & 0.30 & 0.30 & 0.30 & 0.30 \\
\hline Sodium (\%) & 0.16 & 0.16 & 0.16 & 0.16 \\
\hline Crude fiber (\%) & 2.74 & 2.74 & 2.74 & 2.74 \\
\hline
\end{tabular}

Mineral nucleus composed of Limestone, Sodium Chloride (Common Salt-3.85\%), Dicalcium Phosphate, Calcium lodate, Copper Sulfate, Iron Sulfate, Manganese Sulfate, Sodium Selenite, Zinc Oxide, Folic Acid, Nicotinic Acid, Choline Chloride, Biotin, Calcium Pantothenate, Vitamins (A, B1, B2, B6, B12, D3, E and K3), DL-Methionine, Antioxidant Additive (BHT), Zinc Bacitracin and Vehicle. ${ }^{1}$ Warranty levels per kg of premix: Folic Acid (min.) $900.0 \mathrm{mg}$; Pantothenic Acid (min.) 12,000.00 mg; Biotin (min.) 77.0 mg; Calcium (min. - max.) 130.0 - 143.7g; Niacin (min.) 40,000.0 mg; Selenium (min.) 370.0 mg; Vitamin A (min.) 8,800,000.0 IU; Vitamin B1 (min.) 2,500.0 mg; Vitamin growth 0.04 g; Antioxidant 0.02 g; Mn 75 mg; Zn 50 mg; Cu 8 mg; I 0.75 mg; Fe 50 mg. Copper (min.) 7,000.0 mg; iron (min.) 50.0 g; 1,500.0 mg; manganese (min.) 67.5 g; zinc (min.) $45.6 \mathrm{~g}$.

\section{Animal performance}

Eggs were collected daily at 08:00 hours. The average egg production was obtained by calculating the number of all eggs produced per experimental unit. Collectable eggs excluded broken eggs and abnormal eggs (eggs with soft shells and shelled), both expressed as percentage. The total number of dead quails was recorded, and the number of deaths was subtracted from the total number of live quails.
The values were converted into percentage at the end of the experimental period to verify the viability of production and expressed as percentage.

Feed intake (g/quail/day) was evaluated by the amount of feed consumed as a function of the number of quails of each treatment. The total feed intake ratio was the feed conversion per dozen eggs in $\mathrm{kg}$ divided by dozen eggs produced $(\mathrm{kg} / \mathrm{Dz})$ in the period. Feed conversion was calculated using egg mass by 
dividing feed intake in kilograms by total egg mass $(\mathrm{kg} / \mathrm{kg})$.

\section{Egg quality}

All intact eggs produced in each replication were weighed during the last two days of each experimental period to obtain the average egg weight of each replication. At the end of the experimental period $\left(28^{\text {th }}\right.$ day), six eggs were collected per experimental replication and identified according to treatment. They were taken to the Meat Technology Laboratory of FCA/UFGD and weighed individually using a semi-analytical scale (0.01 g precision). Next, the egg specific gravity was measured by immersion of eggs in buckets with different saline solutions ( $\mathrm{NaCl}$ ), whose densities ranged from 1.065 to 1.100 , with intervals of 0.005 , according to the methodology described by Castelló, Pontes, \& Franco (1989). The eggs were broken, and the shells were separated from the yolk and albumen on a flat surface for color evaluation using a portable colorimeter Minolta CR 410. The parameters $L^{*}$ (luminosity), $a^{*}$ (red), and $b^{*}$ (yellow) were evaluated. The readings were taken at three different points on the yolk surface.

The yolk and albumen diameter were evaluated using a caliper mounted in a tripod. The yolk height in the central region and the albumen height about $2 \mathrm{~cm}$ from the yolk were measured. Then, the egg constituents were weighed on a digital scale with an accuracy of $0.01 \mathrm{~g}$ to evaluate the percentage of shell, egg, and albumen taking into account the total egg weight. For the evaluation of shells, after breaking the eggs, they were washed and dried in a forced air ventilation oven at $65^{\circ} \mathrm{C}$ for 72 hours. Then, they were weighed on a digital precision scale and the percentage of shells was calculated considering the total egg weight.

The Haugh unit was determined using the formula $\mathrm{UH}=100 \log (\mathrm{H}+7.57-1.7 \mathrm{~W} 0.37)$, where $\mathrm{H}=$ dense albumen height $(\mathrm{mm})$ and $\mathrm{W}$ = egg weight (g) (Alleoni \& Antunes, 2001). The yolk index was calculated by the ratio between the height and the diameter of this structure. The $\mathrm{pH}$ was obtained using a digital $\mathrm{pH}$ meter. The $\mathrm{pH}$ of the yolk and the albumen of each sample was determined.

\section{Biochemical profile of blood}

Blood samples were collected by intracardiac puncture in two quails slaughtered in each experimental replication. Then, the samples were immediately centrifuged for serum separation and then frozen at $-20^{\circ} \mathrm{C}$ until the time of analyses. Morphine phosphatase $(\mathrm{AF})$, alanine aminotransferase (ALT), urea, cholesterol, triglycerides, serum sodium $(\mathrm{Na})$, potassium (K), and chlorine $(\mathrm{Cl})$ concentrations were determined. Biochemical tests were processed with spectrometry (BioPlus 200) according to the recommendations of the manufacturer of the commercial kit (GoldAnalis ${ }^{\circledR}$ ).

\section{Statistical analysis}

The values were submitted to analyses of normality of residues using the Shapiro Wilk test and homogeneity of variances using the Levene's test. The data that presented disparity were transformed and the analysis of variation was performed using the MIXED 
procedure of SAS 9.3. The means found for each treatment for the variables studied were compared by Tukey test, also adjusted by the MIXED procedure. The significance level for all analyses was $5 \%$.

\section{Results and Discussion}

There were no statistical differences $(p<0.05)$ between treatments for the variables feed intake (g/quail/day), egg production (\%), conversion by mass, conversion by dozen eggs, and marketable eggs, as Table 2 shows.

Table 2

Performance of quails fed with different homeopathic products

\begin{tabular}{|ccccccc|}
\hline Variables & Control & Carbonate & FertSigo $^{{ }}$ & OvoSigo $^{\circledR}$ & P.Value & SEM \\
\hline FC & 38.712 & 40.89 & 40.017 & 40.568 & 0.1553 & 0.375 \\
EP & 84.75 & 83.42 & 88.333 & 86.416 & 0.5226 & 1.20 \\
CM & 4.885 & 5.305 & 5.031 & 5.284 & 0.3605 & 0.096 \\
CD & 3.668 & 3.948 & 3.612 & 3.803 & 0.1779 & 0.058 \\
ME & 80.50 & 80.50 & 84.332 & 82.083 & 0.7109 & 1.298 \\
V & 98.50 & 97.70 & 98.80 & 98.60 & --- & --- \\
\hline
\end{tabular}

Media followed by different letters on the same line differ from each other by the Tukey test $(p<0.05)$. *descriptive analysis. EPM: Standard Media Error. FC: Feed Consumption (g/quail/day). EP: Egg Production (\%). CM: Conversion by mass. CD: Conversion by dozen. ME: Marketable eggs. V: Viability (\%)*.

In the present study, homeopathic doses intended to improve the health and production of healthy quails, therefore the homeopathic substance did not affect pathogens. These results are similar as those found by Brunelli et al. (2018), who did not find significant performance-related effects when evaluating the inclusion of different combinations of passion fruit (Passiflora alata) and chamomile (Matricaria chamomilla) as an herbal additive in the diet of Japanese quails.

Similarly, Silva et al. (2010) did not obtain significant results for quail productivity by adding Kava-kava, one of the primary medicinal plants used as an herbal additive in quail diet. The authors attributed the lack of significant results to alternative medicine (homoeopathy and phytotherapy) due to the rusticity of Japanese quails, reporting that Japanese quails are highly adaptable to various climates and pathogens, thus maintaining a high productivity.

The data found for productivity are within the parameters cited by Ferronato et al. (2020) as the conventional margin of laying of one egg per quail per day. In the present study, the average was above the reference value. This may be justified by the environmental conditions to which the quails were submitted, ensuring thermal comfort, which provided a higher feed intake because of the feeding behavior of these quails associated with the mechanisms of heat production and loss.

According to Valentim et al. (2020), the ideal average egg weight of Japanese quail eggs is $10 \mathrm{~g}$, similar as that found in the 
treatments control and calcium carbonate in the present study. However, the treatments with Fertsigo ${ }^{\circledR}$ and Ovosigo ${ }^{\circledR}$ reached values above the reference ones. These data prove that the use of homoeopathy in quails shows a positive result. This is because the internal components of eggs were produced due to hormonal stimuli, which were submitted to the influence of homoeopathy, due to the positive tropism of the medication in the reproductive tract, as elucidated by the principle of similarity described by Hahnemann (Boyd, 1993), thus resulting in an increased weight of egg components.

According to the data related to egg quality presented in Table 3 , the treatments with Fertsigo ${ }^{\circledR}$ and Ovosigo $^{\circledR}$ had the best effects ( $p>0.05$ ) for egg weight, yolk weight, albumen weight, and shell percentage compared to other treatments.

Table 3

Quality of quail eggs fed with different homeopathic products

\begin{tabular}{|c|c|c|c|c|c|c|}
\hline Variables & Control & Carbonate & FertSigo $^{\circledR}$ & OvoSigo $^{\circledR}$ & P-Value & SEM \\
\hline Egg weight (g) & $10.75 b$ & $10.739 b$ & $11.120 \mathrm{a}$ & $11.224 \mathrm{a}$ & 0.0002 & 0.057 \\
\hline Shell weight (g) & 0.810 & 0.809 & 0.787 & 0.804 & 0.4565 & 0.006 \\
\hline Albumen weight (g) & 6.652 b & $6.608 b$ & $6.934 \mathrm{a}$ & $6.961 \mathrm{a}$ & 0.0001 & 0.040 \\
\hline Yolk weight (g) & $3.224 b$ & $3.296 \mathrm{ab}$ & $3.399 \mathrm{a}$ & $3.422 \mathrm{a}$ & 0.0040 & 0.027 \\
\hline Albumen height & 4.512 & 4.396 & 4.416 & 4.210 & 0.1163 & 0.059 \\
\hline Yolk height & 10.842 & 10.817 & 10.851 & 10.744 & 0.8737 & 0.050 \\
\hline Diameter of yolk & 23.640 & 23.899 & 23.928 & 23.494 & 0.1163 & 0.095 \\
\hline Yolk index & 0.459 & 0.454 & 0.455 & 0.463 & 0.3997 & 0.002 \\
\hline Specific Gravity & 1.072 & 1.070 & 1.069 & 1.071 & 0.1449 & 0.0004 \\
\hline$\%$ Yolk & 30.083 & 30.667 & 30.545 & 30.598 & 0.4089 & 0.142 \\
\hline \%Shell & $7.234 \mathrm{c}$ & $7.437 b$ & $7.483 b$ & $7.571 \mathrm{a}$ & 0.0001 & 0.050 \\
\hline \% Albumen & 62.347 & 61.824 & 62.371 & 62.246 & 0.4685 & 0.130 \\
\hline Haugh Unit & 89.949 & 89.334 & 89.223 & 87.980 & 0.0523 & 0.335 \\
\hline$L^{*}$ & 55.293 & 56.063 & 55.134 & 55.650 & 0.0752 & 0.166 \\
\hline$a^{*}$ & -3.012 & -3.302 & -3.010 & -3.116 & 0.2477 & 0.067 \\
\hline$b^{*}$ & 19.382 & 19.036 & 19.071 & 20.482 & 0.0556 & 0.22 \\
\hline $\mathrm{pH}$ Yolk & 6.197 & 6.157 & 6.173 & 6.198 & 0.4036 & 0.009 \\
\hline pH Albumen & 9.074 & 9.075 & 9.098 & 9.048 & 0.5578 & 0.006 \\
\hline
\end{tabular}

Media followed by different letters on the same line differ from each other by the Tukey test $(p<0.05)$. ${ }^{*}$ descriptive analysis. SEM: Standard Media Error. 
The treatment with Ovosigo ${ }^{\circledR}$ provided a higher percentage of shells $(p<0.05)$, which may be an indicator of a greater availability of calcium in the feed formulation. Hajra, Tyagi, Tyagi, Mandal and Mir (2018) worked with different homoeopathic products and concluded that the drugs Kali phos ${ }^{\circledR}$ and Calc carb $^{\circledR}$, when added to the diet of quails, improve the shell quality during a hot and humid summer.

One of the main problems of the production of quail eggs is the loss of eggs due to poor shell quality, generating a higher number of deformed eggs with cracks, which cannot be made available for consumption due to various types of contamination (Oliveira, Santos, \& Cunha, 2014). The shell is composed of calcium carbonate (98\%) and glycoproteins (2\%). Its primary function is to protect the egg externally. In addition, it has thousands of pores for gas exchange (Rodrigues \& Ávila, 2017).
All calcium salts secreted in the uterine lumen during shell formation derived from blood, and high calcium levels are obtained through feeding and in bones (Hajra et al., 2018). The biochemical profile is a widely used tool in monitoring the health of animals and can be used to monitor quail health and identify possible subclinical diseases.

There were no significant differences $(p>0.05)$ between treatments for the parameters evaluated, as Table 4 shows. The values found for serum creatinine levels are similar as those reported by Schossler, Müller and Serafini (2013). The authors obtained results ranging from 0.1 to $0.5 \mathrm{mg} /$ $\mathrm{dL}$. Alkaline phosphatase in quails suggests a higher cellular production associated with calcium and phosphorus metabolism, with a meaningful participation in the growth of quails (C. S. Souza et al., 2017). The increase in this enzyme indicates bone growth, secondary nutritional hyperparathyroidism, fracture stabilization, and pre-ovulation phase in broilers (Campbell \& Trall, 2006).

\section{Table 4}

\section{Blood parameters of quails fed with different homeopathic products}

\begin{tabular}{|c|c|c|c|c|c|c|}
\hline Parâmetros & Control & Carbonate & FertSigo $^{\circledR}$ & OvoSigo $^{\oplus}$ & SEM & P-Value \\
\hline Alkaline phosphatase (mg/dL) & 1433.00 & 1262.75 & 1292.75 & 1251.00 & 7.55 & 0.3000 \\
\hline Alanine aminotransferase $(\mu \mathrm{l} / \mathrm{dL})$ & 6.6250 & 4.500 & 10.500 & 6.000 & 0.71 & 0.0381 \\
\hline Creatinine (mg/dL) & 0.300 & 0.325 & 0.33750 & 0.3500 & 0.43 & 0.9665 \\
\hline Urea (mg/dL) & $8.25 b$ & $7.00 \mathrm{~b}$ & $10.250 b$ & $19.00 a$ & 1.08 & 0.0251 \\
\hline Cholesterol (mg/dL) & 128.50 & 113.00 & 93.250 & 130.500 & 9.11 & 0.1178 \\
\hline Triglycerides (mg/dL) & 254.750 & 287.25 & 349.00 & 223.750 & 8.83 & 0.2048 \\
\hline **NA (mol/l) & 146.425 & 149.275 & 150.175 & 142.250 & 13.67 & 0.2100 \\
\hline${ }^{* *} \mathrm{~K}(\mathrm{mmol} / \mathrm{l})$ & 4.627 & 3.320 & 3.3825 & 3.667 & 0.97 & 0.3717 \\
\hline${ }^{* *} \mathrm{Cl}(\mathrm{mmol} / \mathrm{l})$ & 108.150 & 108.270 & 106.800 & 105.755 & 8.12 & 0.9014 \\
\hline
\end{tabular}

Media followed by different letters in the line differ from each other by the tukey test at 5\% probability. EPM: Standard average error. **Serum concentration of Sodium (Na), Potassium (K) and Chlorine $(\mathrm{Cl})$. 
The data found in the present study are similar as those found by J. E. S. Silva, Moura, \& Nogueira (2012). The authors did not verify differences in cholesterol and triglyceride values when evaluating the effects of different fatty acids of phyto-therapeutic origin added to the diets of Japanese quails. The urea concentration is related to protein intake and renal excretion rate; increased urea levels may indicate a glomerular lesion, which is indicative of dehydration or pre-renal azotemia (Gerber, 2017).

The plasma concentration of urea is small in quail urine, ranging from 0 to $5 \mathrm{mg} / \mathrm{dL}$ (Campbell \& Trall, 2006). These data are similar as those found in the present study, where the parameters ranged from 2.3 to $3.25 \mathrm{mg} / \mathrm{dL}$. Sodium and potassium are used as indicators of renal function; in cases of kidney disease in quails, it is possible to observe cases of hyperkalemia and hyperphosphatasemia (Patel, Gyamfi, \& Torres, 2009). Serum sodium concentrations in quails range from 130 to 170 $\mathrm{mmol} / \mathrm{L}$ and potassium from 2.5 to $6 \mathrm{mmol} / \mathrm{L}$ (Rezende, Silva, Guimarães, Lellis, \& Mundim, 2019), which are data analogous to those of the present study.

Contrary to this study, Santos et al. (2014) evaluated the effects of the inclusion of different homoeopathic products on the performance and serum biochemical profile of quails and reported that the homoeopathic product Factor Pro bird ${ }^{\circledR}$ supplied from the 1 st to the 42nd days resulted in decreased cholesterol levels. In short, the serum biochemical profile of quails was considered healthy and without the interference of homoeopathic doses, thus being included in the diet without prejudice to animal health.

The homoeopathic practice is an alternative to allopathic medications. It has a lower cost and its administration is easy because it can be diluted in water or mixed with feed or premix (Santos et al., 2014). There is a decrease in restraints and possible trauma due to excessive management of animals (L. C. C. Costa et al., 2014). Braccini et al. (2019) emphasized that, regardless of the mode of action of the drugs, it is known that homeopathy balances the organism by stimulating its natural defenses. Thus, the objective of the homeopathic treatment is to stimulate the whole organism to heal instead of specifically attacking microorganisms.

M. F. Souza (2002) stated that the energetic character of homeopathic therapy provides treated animals with reduction of stress, especially in an intensive breeding because it is very different from the natural environment. Animals grown in low conditions of stress develop their quality production potential better, ensuring a greater survival. Thus, the application of homoeopathy in the production of quails should be further studied seeking new doses, levels of inclusion in diets, and forms of offering the drug to quails.

\section{Conclusion}

The homoeopathic products Fertsigo ${ }^{\circledR}$ and Ovosigo ${ }^{\circledR}$ improves egg weight and acts in the formation of yolk, shells, and albumen with a greater weight. The dose of $0.02 \mathrm{~g} /$ quail/day in the diet is recommended. 


\section{Acknowledgements}

"This study was financed in part by the Coordenação de Aperfeiçoamento de Pessoal de Nível Superior - Brasil (CAPES) Finance Code 001." We would like to thank the support of the SIGO Homeopathic and Department of Veterinary Medicine of the Centro Universitário da Grande Dourados.

\section{References}

Alleoni, A. C. C., \& Antunes, A. J. (2001). Unidade Haugh como medida da qualidade de ovos de galinha armazenados sob refrigeração. Scientia Agricola, 58(4), 681-685. doi: 10.1590/S0103-90162001000400005

Biswas, A., Mohan, N., Raza, M., Mir, N. A., \& Mandal, A. (2019). Production performance, immune response and blood biochemical parameters in broiler broilers fed diet incorporated with prebiotics. Journal of Animal Physiology and Animal Nutrition, 103(2), 493-500. doi: 10.1111/ jpn.13042

Boyd, H. W. (1993). Introdução à medicina homeopática. São Paulo: Santos.

Braccini, G. L., Casetta, J., Silva, S. C. C. da, Oliveira Carniatto, C. H. de, Santos, V. D. R. dos, \& Costa, V. F. (2019). Aplicação da homeopatia na produção animal. Revista Valore, 4(1), 310-323. doi: 10.22408/reva4 02019333310-323

Brunelli, P. F., Romania, H. F., Cultri, G. R. S., Santos, H. V., Dias, L. T. S., \& Silva, J. D. T. (2018). Bem-estar e qualidade de ovos de codornas alimentadas com extratos de camomila e passiflora. Boletim de Indústria Animal, 75(1), 1-11. doi: 10.17523/bia.20 18.v75.e1432
Campbell, T. W., \& Trall, M. A. (2006). Hematologia e bioquímica clínica veterinária.

Castelló, J. A., Pontes, M., \& Franco, F. (1989). Producción de huevos. Real Escuela de Avicultura, 22(2), 58-71.

Chacher, M. F. A., Kamran, Z., Ahsan, U., Ahmad, S., Koutoulis, K. C., Din, H. Q. U., \& Cengiz, Ö. (2017). Use of mannan oligosaccharide in broiler diets: an overview of underlying mechanisms. World's Poultry Science Journal, 73(4), 831-844. doi: 10.1017/S00 43933917000757

Costa, L. C. C., Fo., Queiroz, V. L. D., Souza, M. F. D. A. de, Zúccari, C. E. S. N., \& Costa, E. V. da. (2014). Homeopatia aplicada à reprodução animal. Arquivos de Ciências Veterinárias e Zoologia da UNIPAR, 17(1), 63-68. doi: 10.25110/arqvet.v17i1.2014.4919

Costa, N. C., Araújo, R. L. de, \& Freitas, G. B. L. de. (2009). Homeopatia: um campo terapêutico fundamental no cuidado veterinário de animais de produção. Revista Salus, 3(2), 73-89. Recuperado de https://revistas.unicentro.br/index.php/ salus/article/view/1448/1528

Cowieson, A. J., \& Kluenter, A. M. (2019). Contribution of exogenous enzymes to potentiate the removal of antibiotic growth promoters in poultry production. Animal Feed Science and Technology, 250(1), 8192. doi: 10.1016/j.anifeedsci.2018.04.026

Ferdous, M. F., Arefin, M. S., Rahman, M. M., Ripon, M. M. R., Rashid, M. H., Sultana, M. R.,... Rafiq, K. (2019). Beneficial effects of probiotic and phytobiotic as growth promoter alternative to antibiotic for safe broiler production. Journal of Advanced Veterinary and Animal Research, 6(3), 409. doi: 10.5455/ javar.2019.F361 
Ferronato, C., Bittencourt, T. M., Lima, H. J. D., Valentim, J. K., Martins, A. C. S., \& Silva, N. E. M. (2020). Farelo de algodão na dieta de codornas japonesas. Boletim de Indústria Animal, 77(1), 1-8. doi: 10.17523/bia.2020. v77.e1468

Gandra, J. R., Nunes Gil, P. C., Gandra, E. R. S., Takiya, C. S., \& Gobesso, A. A. O. (2017). Addition of increasing doses of ricinoleic acid from castor oil (Ricinus communis L.) in horse diets: intake, digestibility, glucose and insulin dynamic. Journal of Applied Animal Research, 45(1), 71-75. doi: 10.10 80/09712119.2015.1125354

Gerber, F. (2017). Diagnóstico e estadiamento da doença renal crônica em cães. Revista Científica de Medicina Veterinária, 4(2), 46-61. Recuperado de http://revista. faciplac.edu.br/index.php/Revet/article/ view/332/180

Hajra, D. K., Tyagi, P. K., Tyagi, P. K., Mandal, A. B., \& Mir, N. A. (2018). Influence of homeopathic medicines and feeding regimen on egg shell quality of layers in hot and humid summer. Indian Journal of Poultry Science, 53(1), 60-63. doi: 10. 5958/0974-8180.2018.00022.3

Lemos, M. D., Calixto, L. F., Souza, D., Torres, K. A., Reis, T., Coelho, L., \& Araújo, C., Fo. (2017). Efeito de diferentes aditivos zootécnicos sobre a qualidade de ovos em duas fases produtivas da codorna. Arquivo Brasileiro de Medicina Veterinária e Zootecnia, 69(3), 751-760. doi: 10.1590/1678-4162-9266

Oliveira, H. F., Santos, J. S., \& Cunha, F. D. A. (2014). Utilização de alimentos alternativos na alimentação de codornas. Revista Eletrônica Nutritime, 11(5), 3683-3690. Recuperado de http://nutritime.com.br/ arquivos internos/artigos/ARTIGO272.pdf
Patel, D. R., Gyamfi, R., \& Torres, A. (2009). Exertional rhabdomyolysis and acute kidney injury. The Physician and Sportsmedicine, 37(1), 71-79. doi: 10.3810 /PSM.2009.04.1685

Pires, M. (2005). A homeopatia para os animais. (Comunicado Técnico, INFOTECA-E). Juiz de Fora: EMBRAPA Gado de Leite. Recuperado de https://www.infoteca. cnptia.embrapa.br/bitstream/doc/595 885/1/COT46Ahomeopatiaparaosani mais.pdf

Rezende, M. S., Silva, P. L., Guimarães, E. C., Lellis, C. G., \& Mundim, A. V. (2019). Variações fisiológicas, influência da idade e sexo no perfil bioquímico sanguíneo de aves da linhagem pesada de frango de corte na fase de recria. Arquivo Brasileiro de Medicina Veterinária e Zootecnia, 71(5), 1649-1658. doi: 10.1590/1678-4162-10661

Rodrigues, A. S., \& Ávila, S. G. (2017). Caracterização físico-química da casca de ovo de galinha e utilização como fonte para produção compostos de cálcio. Revista Virtual de Química, 9(4), 596-607. Recuperado de http://static.sites.sbq.org. br/rvq.sbq.org.br/pdf/v9n2a10.pdf

Rostagno, H. S., Albino, L. F. T., Donzele, J. L., Gomes, P. C., Oliveira, R. D., Lopes, D. C.,... Euclides, R. F. (2017). Composição de alimentos e exigências nutricionais. Tabelas brasileiras para aves e suínos.

Santos, F. R., Santana, R. O., Carvalho, E. D. A., Costa, N. A., Minafra, C. S., \& Oliveira, P. R. (2014). Desempenho e perfil sérico bioquímico de frangos de corte alimentados com rações contendo produtos homeopáticos. Revista Brasileira de Saúde e Produção Animal, 15(2), 394-405. doi: 10. 1590/S1519-99 402014000200010 
Schossler, J. E. W., Müller, D. C. D. M., \& Serafini, G. M. C. (2013). Terapia anti-inflamatória em codornas (Coturnix coturnix japonica) com meloxicam calculado por extrapolação alométrica. MEDVEP. Revista Cientítica Medicina Veterinaria, 10(35), 126-131.

Silva, J.D. T., Guarini, A. R., Dias, L. T.S., Hada, F.H., Gravena, R. A., Marques, R. H., \& de Morae, V. M. B. (2010). Kava-kava como aditivo fitoterápico na alimentação de codornas de postura. Biotemas, 23(4), 77-82. doi: 10.5007/2175-7925.2010v23n4p77

Silva, J. E. S., Moura, A. M. A., \& Nogueira, R. A. (2012). Efeito dosácidos graxos essenciais sobre lipidemia e vascularização da membrana vitelina de codornas japonesas. Arquivo Brasileiro de Medicina Veterinária e Zootecnia, 64(6), 1603-1612. doi: 10. 1590/S0102-09352012000600029

Souza Oliveira, D., Andrade, P. A. D., Valentim, J. K., Costa Paiva, A. L. da, Faria, S. R., Velarde, J. M. D. S.,... Alves, J. P. (2020). Homeopatia na alimentação de cordeiros. Research, Society and Development, 9(4), e28942670-e28942670. doi: 10.33448/ rsd-v9i4.2670

Souza, A. V., Morais, M. V. M., Rocha, M. C., Souza, R. M., Valentim, J. K., Pietramale, R. T. R.,... Lima, H. J. D. Á. (2020). Influence of fennel in Japanese Quail Diet over egg quality and behavior aspects. Boletim de Indústria Animal, 77(1), 1-13. doi: 10. 17523/bia.2020.v77.e1477

Souza, C. S., Toledo Barreto, S. L. de, Vieites, F. M., Calderano, A. A., Moraes, G. H. K. de, \& Almeida Oliveira, M. G. de. (2017). Cálcio e fósforo na nutrição de codornas japonesas em postura. Science and Animal Health, 5(3), 260-281. doi: 10.15210/sah. v5i3.9166
Souza, M. F. (2002). Homeopatia veterinária. Anais da Conferência Virtual Global sobre Produção Orgânica de Bovinos de Corte, Campo Grande, MS, Brasil, 1. Recuperado dehttps://www.cpap. embrapa.br/agencia/ congressovirtual/pdf/portugues/02pt02. pdf

Teixeira, M.Z. (2018). Special Dossier:" Scientific evidence for homeopathy". Revista da Associação Medica Brasileira, 64(2), 9394. doi: 10.1590/1806-9282.64.02.93

Teixeira, M. Z., \& Carneiro, S. M. (2017). Efeito de ultradiluições homeopáticas em plantas: revisão da literatura. Revista de Homeopatia, 80(1/2), 113-132. Recuperado de https://www.sermedico. org.br/pdfs/merged_completo.pdf\# page $=117$

Valentim, J. K., Bittencourt, T. M., Lima, H. J. D. À., Barros, F. K. Q., Pereira, I. D. B., Almeida, G. R. D., \& Ziemniczak, H. M. (2020). Natural and synthetic pigments in diet of Japanese quails. Acta Scientiarum. Animal Sciences, 42(1), 1-6. doi: 10.4025/actascianimsci. v42i1.47364

Valentim, J. K., Paula, K. L. C. D., Geraldo, A., Miranda, D. A., Lemke, S. S. R., Oliveira, M. J. K. D., \& Oliveira, J. É. F. D. (2018). Use of probiotics in diets of wild-type broilers and its effects on performance. Revista Brasileira de Saúde e Produção Animal, 19(3), 315-323. doi: 10.1590/s1519-9940 2018000300008 